\title{
POTENSI EKSTRAK BUAH KECIPIR (Psophocarpus tetragonolobus (L.) DC.) SEBAGAI ANTIOSTEOPOROSIS DENGAN PARAMETER PENINGKATAN ALKALIN FOSFATASE PADA TIKUS WISTAR BETINA YANG DIINDUKSI DEKSAMETASON
}

\author{
${ }^{1}$ Nurmala, ${ }^{2}$ Fetri Lestari, ${ }^{3}$ Ratu Choesrina \\ ${ }^{1,2,3}$ Prodi Farmasi, Fakultas Matematika dan Ilmu Pengetahuan Alam, Universitas Islam Bandung, \\ Jl. Tamansari No.1 Bandung 40116 \\ email: ${ }^{1}$ nurmala.sahidin@yahoo.com, ${ }^{2}$ fetrilestari@gmail.com, ${ }^{3}$ choes_rina@yahoo.com
}

\begin{abstract}
ABSTRAK
Kecipir (Psophocarpus tetragonolobus (L.) DC.) merupakan tanaman polong-polongan (Fabaceae) yang mengandung fitoestrogen, berperan dalam mencegah kehilangan massa tulang akibat defisiensi estrogen. Penelitian ini bertujuan untuk mengetahui aktivitas ekstrak etanol buah kecipir sebagai antiosteoporosis berdasarkan kadar ALP (Alkaline phosphatase) plasma pada tikus yang diinduksi deksametason. Tikus dikelompokkan menjadi tiga kelompok yaitu kontrol positif, kontrol negatif dan kelompok uji (ekstrak dosis $500 \mathrm{mg} / \mathrm{kg} \mathrm{BB}$ ). Kelompok kontrol positif dan kelompok uji diberi induksi deksametason $0,1 \mathrm{mg} / \mathrm{kg}$ BB. Pemberian induksi dilakukan selama 29 hari, dan pemberian sediaan uji untuk kelompok uji dilakukan selama 18 hari. Pengukuran kadar ALP dilakukan sebanyak tiga kali yaitu ALP awal, ALP pascainduksi dan ALP pascaterapi. Keberhasilan induksi osteoporosis ditandai dengan adanya penurunan kadar ALP pascainduksi dibandingkan kadar ALP awal. Keberhasilan terapi ditandai dengan adanya peningkatan kadar ALP pascaterapi dibandingkan kadar ALP pascainduksi. Berdasarkan adanya peningkatan kadar ALP plasma pascaterapi pada kelompok uji menunjukkan bahwa ekstrak etanol buah kecipir dosis $500 \mathrm{mg} / \mathrm{kg}$ BB berpotensi sebagai antiosteoporosis.

Kata Kunci: buah kecipir (Psophocarpus tetragonolobus), antiosteoporosis, ALP (Alkaline phosphatase), fitoestrogen
\end{abstract}

\begin{abstract}
Winged bean (Psophocarpus tetragonolobus (L.) DC.) is a legume plant (Fabaceae) containing phytoestrogens and it also contributes to prevent the loss of bone mass due to the estrogen deficiency. This study aims at determining the ethanol extract activity of winged beans as an antiosteoporosis based on the level of plasma ALP (Alkaline phosphatase) in dexamethasoneinduced rats. The rats were grouped into three groups: positive control, negative control, and test group (extract dose of $500 \mathrm{mg} / \mathrm{kg} \mathrm{BW}$ ). The positive control group and the test group were induced by dexamethasone $0.1 \mathrm{mg} / \mathrm{kg} \mathrm{BB}$. The induction was administered for 29 days, and the extract was administered for 18 days. The measurements of ALP levels were performed three times: baseline ALP, post-induction ALP and post-therapy ALP. The successful induction was indicated by a decrease of ALP levels from the baseline ALP levels. The successful therapy was indicated by an increase in post-therapy ALP levels from the post-induction ALP levels. Based on the increase of plasma ALP levels on post-therapy in test group, showed that the extract of wingedbeans dose $500 \mathrm{mg} / \mathrm{kg} \mathrm{BW}$ have activity as antiosteoporosis.
\end{abstract}

Keywords: winged bean (Psophocarpus tetragonolobus), antiosteoporosis, ALP (Alkaline phosphatase), phytoestrogen 


\section{PENDAHULUAN}

Osteoporosis biasa diidentikkan dengan faktor penuaan, namun faktanya dapat juga terjadi pada usia muda akibat gaya hidup. Osteoporosis adalah suatu kondisi yang disebabkan oleh hilangnya zat tulang yang membuat seluruh tulang lebih lemah secara mekanis sehingga cenderung patah tulang (Hurwitz, 2016:1). Pada kondisi ini terdapat perubahan pergantian tulang homeostatis normal, dimana kecepatan resorpsi lebih besar dibandingkan kecepatan formasinya (Suratun dkk., 2008:72).

Osteoporosis dapat dijumpai di seluruh dunia dan sampai saat ini masih merupakan masalah dalam kesehatan masyarakat terutama di negara berkembang. Menurut data WHO diseluruh dunia terdapat sekitar 200 juta orang yang menderita osteoporosis. Patah tulang yang sering terjadi yaitu patah tulang pada paha atas, yang dapat mengakibatkan kecacatan seumur hidup dan kematian. Penelitian terbaru dari International Osteoporosis Foundation (IOF) mengungkapkan bahwa satu dari empat perempuan di Indonesia dengan rentang usia 5080 tahun memiliki resiko terkena osteoporosis. Osteoporosis perempuan di Indonesia 4 kali lebih tinggi dibandingkan laki-laki (Kemenkes RI, 2015:1).

Proses remodeling tulang dikendalikan oleh beberapa hormon yang salah satunya adalah hormon estrogen. Estrogen dapat menghambat aktivitas penyerapan tulang dengan menargetkan osteoklas secara langsung untuk menjalani apoptosis dan menghambat sitokin yang mendorong aktivitas osteoklas (Kameda et al., 1997:489).

Defisiensi estrogen meningkatkan keropos tulang pada setiap usia sehingga meningkatkan intensitas remodeling tulang. Namun ini bukan proses yang positif, karena defisiensi estrogen juga meningkatkan umur osteoklas dan menurunkan umur osteoblas, keseimbangan unit akhir adalah negatif dan semakin sedikit tulang terbentuk (Mario, 2004:15). Pada wanita menopause, dengan defisiensi hormon estrogen dapat berpotensi menderita osteoporosis dan pada akhirnya terancam patah tulang (Anies, 2006:113).

Banyak studi yang membuktikan pentingnya estrogen dalam remodeling tulang, terbukti dari fakta bahwa terapi hormon yang diberikan dengan cara tergantung dosis, secara efektif mencegah keropos tulang pada wanita pascamenopause dan mengurangi terjadinya patah tulang. Namun, berbagai laporan tentang efek samping terapi sulih hormon, seperti penyakit endometrium, kanker payudara dan kejadian tromboemboli, meningkatkan pencarian strategi alternatif dan alami untuk mengatasi kekurangan estrogen menopause, termasuk cara mengelola pencegahan 
osteoporosis akibat penuaan (Ozturk et al., 2008:146). Alternatif lain untuk menangani osteoporosis yaitu dengan mengkonsumsi tanaman yang memiliki kandungan fitoestrogen. Fitoestrogen merupakan hormon tumbuhan dengan struktur kimia menyerupai hormon estrogen manusia. Fitoestrogen dalam sediaan herbal, yaitu flavon tertentu, isoflavon, flavanon, flavonol, koumestan dan lignan, dapat memainkan peran penting dalam melindungi keropos tulang postmenopause. Studi pada tikus ovariektomi telah menunjukkan bahwa fitoestrogen seperti koumestrol, genistein, dan daidzein dapat mengurangi keropos tulang (Leung, 2016:1).

Saat kadar estrogen menurun, banyak reseptor estrogen yang tidak berikatan. Dengan adanya fitoestrogen membuat reseptor estrogen berikatan dengan fitoestrogen dan membantu mengurangi osteoporosis. Oleh karena itu, makanan yang memiliki kandungan senyawa fitoestrogen dapat dijadikan alternatif untuk mengatasi kekurangan estrogen pada wanita menopause.

Tanaman polong-polongan (Fabaceae) terutama kedelai merupakan sumber isoflavon dengan unsur utama genistein dan daidzein. Studi terbaru membuktikan kecipir yang masih satu famili dengan kedelai, memiliki kandungan isoflavon yang besar dari hasil ekstraksinya (Wahyuni,2010:53). Dalam buah kecipir juga terdapat beberapa mineral yang baik untuk tulang, salah satunya kalsium yang sangat dibutuhkan untuk memperbaiki kepadatan tulang.

Penelitian ini bertujuan untuk mengetahui aktivitas ekstrak etanol buah kecipir sebagai antiosteoporosis berdasarkan perubahan pada kadar alkaline phosphatase (ALP) plasma tikus betina yang diinduksi osteoporosis menggunakan deksametason.

Dari hasil penelitian ini diharapkan dapat menemukan tumbuhan yang berkhasiat antiosteoporosis dan diharapkan dapat bermanfaat untuk mengatasi terjadinya osteoporosis terutama yang menghadapi masa menopause.

\section{METODE PENELITIAN}

\subsection{Alat}

Alat yang digunakan antara lain maserator, evaporator, kandang tikus, timbangan analitik, timbangan hewan, jarum suntik, sonde oral, spuit, penangas air, cawan, alat-alat gelas, waterbath, spektrofotomeri UVVis, mikropipet, microtube dan sentrifuga.

\subsection{Bahan}

Bahan yang digunakan antara lain buah kecipir (Psophocarpus tetragonolobus (L.) DC.) yang diperoleh dari Ciamis Jawa Barat, reagen alkaline phosphatase, $\mathrm{CMC}-\mathrm{Na}$, aquades, etanol $70 \%$, deksametason, pereaksi 
untuk skrining fitokimia, pakan tikus dan sekam.

\subsection{Metode}

Pada penelitian ini dilakukan pengujian aktivitas antiosteoporosis dari ekstrak etanol buah kecipir yang dilakukan di Laboratorium Hewan Universitas Islam Bandung. Penelitian melalui beberapa tahapan, yaitu penyiapan bahan, determinasi, skrining fitokimia, pembuatan ekstrak, dan pengujian aktivitas antiosteoporosis melalui pengukuran kadar ALP tikus.

Hewan uji yang digunakan adalah tikus wistar betina yang dibagi menjadi 3 kelompok perlakuan, yaitu : kelompok kontrol negatif, kontrol positif dan kelompok uji (dosis 500 $\mathrm{mg} / \mathrm{kg}$ BB). Semua kelompok perlakuan kecuali kontrol negatif, diinduksi dengan deksametason $0,1 \mathrm{mg} / \mathrm{kg}$ BB selama 29 hari. Pemberian sediaan uji dilakukan selama 18 hari.

Pengukuran kadar ALP dilakukan sebanyak tiga kali yaitu ALP awal, ALP pascainduksi, dan ALP pascaterapi. Pengukuran kadar ALP dilakukan dengan menggunakan spektrofotometri UV-Vis. Aktivitas antiosteoporosis ditentukan berdasarkan peningkatan kadar ALP pascaterapi dibandingkan kadar ALP pascainduksi. Data yang diperoleh dianalisis dengan uji Saphiro Wilk untuk melihat distribusi data, dilanjutkan dengan $T$-test untuk membandingkan kadar ALP antar waktu perlakuan pada masing-masing kelompok dengan taraf kepercayaan 95\%.

\section{HASIL DAN PEMBAHASAN}

\subsection{Determinasi Tumbuhan}

Determinasi dilakukan di Herbarium Jatinangor Laboratorium Taksonomi Tumbuhan Departemen Biologi FMIPA Universitas Padjadjaran. Hasil determinasi menunjukan bahwa simplisia yang digunakan adalah buah kecipir (Psophocarpus tetragonolobus (L.) DC.).

\subsection{Skrining Fitokimia Buah Kecipir}

Skrining fitokimia dilakukan terhadap simplisia dan ekstrak dengan tujuan untuk memastikan adanya senyawa target dalam simplisia, dan memastikan senyawa tersebut tidak rusak setelah dibuat dalam bentuk ekstrak kental. Hasil dapat dilihat pada tabel dibawah ini. 
Tabel 1. Hasil Skrining Fitokimia Simplisia dan Ekstrak Buah Kecipir

\begin{tabular}{|c|c|c|}
\hline Golongan Senyawa & Simplisia & Ekstrak \\
\hline Alkaloid & - & - \\
\hline Flavonoid & + & + \\
\hline Tanin & - & - \\
\hline Saponin & + & - \\
\hline Polifenolat & + & + \\
\hline Kuinon & - & - \\
\hline Monoterpen & - & - \\
\hline Seskuiterpen & - & - \\
\hline Steroid dan Terpenoid & + & + \\
\hline
\end{tabular}

\section{Keterangan:}

$(+)=$ Terdeteksi

$(-)=$ Tidak Terdeteksi

Hasil skrining fitokimia pada simplisia

buah kecipir menunjukkan adanya senyawa flavonoid, saponin, polifenolat, steroid dan terpenoid. Sedangkan pada ekstrak kental, hasil penapisan fitokimia menunjukkan adanya flavonoid, polifenolat, steroid dan terpenoid. Terdapat perbedaan hasil skrining antara simplisia dengan ekstrak, dimana hasil skrining pada ekstrak tidak mengandung saponin.

Senyawa target yang memiliki khasiat sebagai antiosteoporosis adalah fitoestrogen, yang merupakan suatu isoflavon. Isoflavon merupakan senyawa golongan flavonoid. Berdasarkan hasil skrining fitokimia, flavonoid terdapat dalam simplisia dan ekstrak kental buah kecipir.

\subsection{Pengujian Aktivitas Antiosteoporosis}

Parameter pengujian aktivitas antiosteoporosis yang digunakan yaitu berdasarkan peningkatan kadar ALP (Alkaline Phosphatase) pada plasma. ALP merupakan penanda biokimia pembentukan tulang yang ditemukan pada membran plasma osteoblas yang mencerminkan aktivitas osteoblastik pada proses remodeling tulang (Rekha ,2015: 185). ALP berperan penting dalam pembentukan osteoid dan mineralisasi tulang (Vaithialingam et al., 2013: 20). Hasil pengukuran kadar ALP awal, pascainduksi dan pascaterapi yang dilakukan pada percobaan menunjukkan hasil sebagai berikut.

Tabel 2. Pengukuran Kadar ALP (Alkaline phosphatase)

\begin{tabular}{|c|c|c|c|}
\hline \multirow{2}{*}{ Kelompok } & \multicolumn{3}{|c|}{ Rata-rata \pm SD Kadar ALP (UI) } \\
\hline & Awal & Pascainduksi & Pascaterapi \\
\hline Kontrol Negatif & $155,02 \pm 23,00$ & $186,51 \pm 32,72$ & $230,72 \pm 47,76$ \\
\hline Kontrol Positif & $173,79 \pm 57,74$ & $144,45 \pm 49,45$ & $76,905 \pm 43,04$ \\
\hline Uji & $210,73 \pm 42,87$ & $177,97 \pm 67,35$ & $205,89 \pm 95,41$ \\
\hline
\end{tabular}


Pada kelompok kontrol negatif, rata-rata kadar ALP awal sampai kadar ALP pascaterapi terus mengalami kenaikan. Berdasarkan analisis statistik menggunakan T-test menunjukkan kadar ALP tidak perbeda bermakna $(\mathrm{p}<0,05)$ antara ALP pascainduksi dibandingkan ALP awal $(p=0,158)$ dan ALP pascaterapi dibandingkan ALP pascainduksi $(\mathrm{p}=0,346)$. Adanya kenaikan kadar ALP pada kelompok kontrol negatif dapat disebabkan karena faktor makanan yang mungkin dapat berpengaruh pada proses formasi tulang, juga dapat disebabkan karena faktor pergerakan tikus.

Pada kelompok kontrol positif, rata-rata kadar ALP awal terhadap kadar ALP pascainduksi mengalami penurunan, hal ini menunjukkan bahwa sudah terjadi resorpsi tulang akibat dari induksi deksametason. Deksametason berperan dalam resorpsi tulang dengan cara menghambat proliferasi dan diferensiasi sel osteoblas (Shintani et al.,2011: 313). Sebagaimana penelitian yang dilakukan oleh Laswati et al (2015:45), yang menyatakan bahwa pemberian deksametason dosis 0,1 $\mathrm{mg} / \mathrm{kg}$ BB dapat menyebabkan osteoporosis pada tikus. Namun berdasarkan data statistik menggunakan T-test menunjukkan kadar ALP tidak berbeda bermakna $(p<0,05)$ antara ALP awal dengan ALP pascainduksi $(\mathrm{p}=0,329)$. Penurunan kadar ALP ini terus berlanjut sampai pascaterapi. Berdasarkan analisis statistik t-test menunjukan bahwa adanya perbedaan yang bermakna antara kadar ALP pascainduksi dan pascaterapi $(p=0,030)$. Hal ini karena pada pemberian induksi selama 29 hari belum memberikan efek resorpsi tulang yang signifikan, namun resorpsi berlanjut selama periode terapi, dimana kontrol positif hanya diberi suspensi Na CMC 0,5\%. Sehingga masih terdapat efek perusakan oleh induktor setelah induksi dihentikan.

Pada kelompok uji, rata-rata kadar ALP awal terhadap kadar ALP pascainduksi mengalami penurunan. Penurunan kadar ALP ini menandakan bahwa tikus telah terinduksi, meskipun berdasarkan analisis statistik menggunakan T-test menunjukkan perbedaan kadar ALP tidak berbeda bermakna $(\mathrm{p}<0.05)$ antara ALP awal dengan ALP pascainduksi $(p=0,523)$, seperti halnya pada kelompok kontrol positif.

Setelah diberi terapi dengan ekstrak buah kecipir, kadar ALP pada kelompok uji mengalami peningkatan, meskipun berdasarkan analisis statistik menggunakan $T$ test tidak menunjukkan perbedaan yang bermakna antara ALP pascainduksi dengan ALP pascaterapi $(p=0,797)$. Kenaikan kadar ALP pascaterapi yang tidak berbeda bermakna secara statistik ini, dapat dihubungkan dengan adanya efek resorpsi yang terus berlanjut 
setelah induksi dihentikan seperti pada ALP pascaterapi sudah mendekati kadar ALP kelompok kontrol positif. Namun bila awal sebelum tikus diberi perlakuan apapun. dibandingkan, kadar ALP pascaterapi dengan Bila dilakukan selisih data antar waktu kadar ALP normal kelompok uji yaitu ALP perlakuan, didapatkan hasil kadar selisih yaitu awal, menunjukan perbedaan kadar yang tidak sebagai berikut. berbeda bermakna $(\mathrm{p}=0,951)$, artinya kadar

Tabel 3. Selisih Kadar ALP (Alkaline Phosphatase)

\begin{tabular}{|c|c|c|}
\hline \multirow{2}{*}{ Kelompok } & \multicolumn{2}{|c|}{ Rata-rata \pm SD Selisih Kadar ALP (UI) } \\
\hline & Pascainduksi & Pascaterapi \\
\hline Kontrol Negatif & $31,48 \pm 24,73$ & $44,21 \pm 62,65$ \\
\hline Kontrol Positif & $-59,34 \pm 80,37$ & $-37,54 \pm 11,54$ \\
\hline $\mathrm{Uji}$ & $-32,09 \pm 72,45$ & $27,25 \pm 161,38$ \\
\hline
\end{tabular}

Keterangan :

Pascainduksi $\quad=$ kadar ALP induksi - kadar ALP awal

Pascaterapi $=$ kadar ALP pascaterapi - kadar ALP pascainduksi

Berdasarkan tabel 3 di atas, menunjukan deksametason. Kemudian pada selisih kadar bahwa pada kelompok kontrol negatif tidak ALP pascaterapi, kadar ALP mengalami mengalami penurunan kadar ALP pada kenaikan, menandakan adanya efek ekstrak pascainduksi dan pascaterapi, karena pada buah kecipir pada formasi tulang. kelompok ini tidak diinduksi osteoporosis dengan deksametason. Sedangkan pada 2. KESIMPULAN

kelompok kontrol positif, kadar ALP buah kecipir (Psophocarpus tetragonolobus pascainduksi dan pascaterapi terus mengalami (L.) DC.) dosis $500 \mathrm{mg} / \mathrm{kg} \mathrm{BB}$ mempunyai penurunan, disebabkan karena kelompok ini diinduksi osteoporosis dengan deksametason namun pada periode terapi hanya diberi suspensi Na CMC 0,5\%. Hal ini menunjukkan bahwa pemberian deksametason telah berhasil efek sebagai antiosteoporosis pada kelompok uji berdasarkan parameter peningkatan kadar Alkaline Phosphatase (ALP) pascaterapi dibandingkan dengan kadar ALP pascainduksi deksametason.

menyebabkan osteoporosis pada tikus.

Pada kelompok uji, kadar ALP pascainduksi mengalami penurunan, artinya terjadi resorpsi tulang akibat induksi dengan 


\section{DAFTAR PUSTAKA}

Anies, 2006. Waspada Ancaman Penyakit Tidak Menular Solusi Pencegahan dari Aspek perilaku dan Lingkungan. Gramedia : Jakarta.

Hurwitz, 2016. Osteoporosis and Fracture. J Osteopor Phys Act. 4(4): 72.

Kameda T, et al., (1997). Estrogen inhibits bone resorption by directly inducing apoptosis of the bone-resorbing osteoclasts. Journal of Experimental Medicine. 186(4): 489.

Kemenkes RI., 2015. Pusat Data dan Informasi - Osteoporosis. Kementrian Kesehatan RI Jakarta.

Laswati et al., 2015. Efek Pemberian Spilanthes Acmella Dan Latihan Fisik Terhadap Jumlah Sel Osteoblas Femur Mencit Yang Diinduksi Deksametason. Media Litbangkes. 25 (1): 45.

Leung PC, 2016. Herbal Medicine for General and Disuse Osteoporosis. J Osteopor Phys Act. 4: 2.

Mario CL dan Loredana M.,2005. Utility Of Dietary Phytoestrogens In Preventing Postmenopausal Osteoporosis. Current Topics in Nutraceutical Research. 3(1): 15.

Ozturk Turhan, $\mathrm{N}$ et al., 2008. The Effect of Isoflavones on Bone Mass and Bone
Remodelling Markers in Postmenopausal Women. Turk J Med Sci. 38(2):146.

Shintani et al., 2011. Differential Effects

Of Dexamethasone On The Chondrogenesesis Of Mesenchymal Stromal Cells: Influence Of Microenvironment, Tissue Origin And Growth Factor. European Cells and Materials. 22: 313.

Rekha S. P., 2015. Comparitive study of Biochemical bone turnover markers in pre \& post-menopausal women. International Journal of Applied Research. 1(5): 185.

Suratun dkk,. 2008. Klien Gangguan Sistem Muskuloskeletal : Seri Asuhan Keperawatan. EGC:Jakarta.

Vaithialingam et al., 2013. Alkaline Phosphatase levels in Rheumatoid Arthritis and Osteoporosis in clinical practice. Journal of Current Trends in Clinicl Medicine \& Laboratory Biochemistry. 1(2): 20.

Wahyuni, 2010. Karakterisasi Senyawa Bioaktif Isoflavon dan Uji Aktivitas Aantioksidan dari Ekstrak Tempe Berbahan Baku Buncis (Phaseolus vulgaris) dan Kecipir (Psophocarpus tetragonolobus). Program Pasca Sarjana Biosains Universitas Sebelas Maret Surakarta. 